\title{
Pre-treatment of Soy Slurry with Viscozyme $L$ and the Concentration of Sugars and Isoflavones and the Microstructure of Silken Tofu
}

\author{
Michele Rosset ${ }^{1, *}$, Adelaide Del Pino Beléia ${ }^{2}$ \\ ${ }^{1}$ Instituto Federal de Educação, Ciência e Tecnologia do Paraná, Jacarezinho, Paraná, Brazil \\ ${ }^{2}$ Departamento de Ciência e Tecnologia de Alimentos, Centro de Ciências Agrárias, Universidade Estadual de Londrina, Londrina, \\ Paraná, Brazil \\ *Corresponding author: michele.rosset@ifpr.edu.br
}

Received March 19, 2014; revised April 21, 2014; accepted April 22, 2014

\begin{abstract}
Silken tofu which retains soluble solids present in the soymilk was investigated for differences in the microstructure, sugars and isoflavones content from regular silken. Soy slurry treated with Viscozyme L $(2.5 \mathrm{~mL} / \mathrm{L})$ was incubated for 30 minutes at $55^{\circ} \mathrm{C}$. Stachyose was the predominant oligosaccharide in treated tofu, $4.58 \mathrm{~g} / 100 \mathrm{~g}$ and $3.30 \mathrm{~g} / 100 \mathrm{~g}$ in control tofu, raffinose content was 1.21 and $0.75 \mathrm{~g} / 100 \mathrm{~g}$ in treated and control tofu, respectively. Glucose was approximately duplicated in treated tofu (1.66 g/100 g) compared to control $(0.74 \mathrm{~g} / 100 \mathrm{~g})$ while fructose content was three times higher $(1.09 \mathrm{~g} / 100 \mathrm{~g})$. Comparing isoflavones content, malonyl conjugates were double the amount of the control tofu, with the exception of malonylgenistin, but the total amount of isoflavones was not different. The tofu of the treated slurry showed a fibrous three-dimensional network structure, but with larger protein aggregates and was more tightly connected than the control.
\end{abstract}

Keywords: carbohydrase, oligosaccharides, soybean curd, scanning electron microscopy

Cite This Article: Michele Rosset, and Adelaide Del Pino Beléia, "Pre-treatment of Soy Slurry with Viscozyme L and the Concentration of Sugars and Isoflavones and the Microstructure of Silken Tofu." Journal of Food and Nutrition Research, vol. 2, no. 3 (2014): 130-135. doi: 10.12691/jfnr-2-3-7.

\section{Introduction}

Soybean is one of the major food sources worldwide providing proteins, oil, carbohydrates, bioactive compounds like isoflavones, and many other nutrients to humans and animals. Soybean contains approximately $40 \%$ protein, $20 \%$ oil, and $33 \%$ carbohydrates and up to $16.6 \%$ of the carbohydrates are soluble sugars or oligosaccharides. Glucose, fructose, sucrose, raffinose and stachyose comprise almost $99 \%$ of the soybean soluble sugars [1].

Twenty eight Brazilian cultivars analysed in 2010 had concentration of stachyose that varied from 2.69 to 3.69 $\mathrm{g} / 100 \mathrm{~g}$, raffinose from 0.48 to $1.19 \mathrm{~g} / 100 \mathrm{~g}$ and sucrose from 3.25 to $5.95 \mathrm{~g} / 100 \mathrm{~g}$. In this same report BRS 267 had $2.23 \%$ of stachyose, $0.94 \%$ of raffinose and $5.95 \%$ of sucrose. The use of cultivar BRS 267 can improve the sensory quality of soy products like tofu and soymilk due to the high sucrose content and could mask astringency, beany flavor and other flavorful compounds such as saponins and isoflavones [2].

Sugars affect soy food quality and nutritional values. Soluble sugars, especially sucrose, are the major source of energy for fermentation and contribute to the sweetness of soymilk and tofu. Increased total sugar and sucrose content is important to achieve the proper rate of fermentation during the natto-making process and to improve the taste and flavor of natto and tofu [3].

Although oligosaccharides, including raffinose and stachyose, are considered undesirable sugars in soybean, because they are not readily digestible and cause flatulence or diarrhoea, they can act as prebiotcs or as a source of soluble dietary fiber [4].

In addition, soybeans contain others health benefiting phytochemicals of which isoflavones have been reported to be the most important. Numerous reports have indicated that isoflavones may possess the biological activities to inhibit menopause symptoms in women, cancer cell proliferation and oxidative stress [5,6,7]. There are 12 chemical forms of isoflavones in soybeans and soy foods, consisting of 3 chemical forms that are aglycons and the 9 conjugated compounds as $\beta$-glucoside, malonyl- $\beta$ glucoside, acetyl- $\beta$-glucoside [8]. It has been established that their chemical form in foods can influence the bioavailability of isoflavones and that the compounds may be altered since they are susceptibility to degradation and alteration especially during heating [9].

The concentrations of each of these forms will vary in soy foods depending upon the type of processing. In soy foods that are processes with water, the native soy $\beta$ glucosidases will be active prior to any heat treatment generating aglycons as it happens during the soaking of soybeans prior to processing into soymilk. Heat treatment of moist soy foods, as in soymilk and tofu, will tend to 
generate $\beta$-glucosides at the expense of the malonyl forms. Tofu is a traditional oriental soybean food made by the coagulation of soluble proteins with a calcium or magnesium salt or glucono- $\delta$-lactone (GDL), from hotwater extract of whole soybeans. Glucono- $\delta$-lactone, is an acid precursor used as a protein coagulant especially in making "silken" that have a shelf-life is greatly extended when compared to soft tofu. Without removing the whey from the curd, GDL-coagulated silken tofu has a custardlike texture and smooth mouth feel [8].

Treatment of protein with proteases is common, but less studied is the hydrolysis of carbohydrates in soybeans by carbohydrases. The addition of the carbohydrase in soy slurry before obtaining the soymilk may result in tofu with technological properties and composition different from the traditional tofu, especially in the concentration of sugars to increase the sweetness of the product. The use of a multienzymatic complex, such as Viscozyme L, which contains cellulases, arabinases, hemicellulases, gluconases and xylanases [10], may cause the hydrolysis of the carbohydrates in cell walls, favoring the extraction of useful compounds (protein and sugars) from the vegetable tissues. Silken tofu product was chosen because the products of the hydrolysis are water-soluble and in a soft tofu (pressed) these sugars would be eliminated in the whey.

The presence of low molecular weight co-solutes such as sugars in the aqueous phase of food systems can alter the conformation and interactions of proteins by binding to protein surface groups [11]. The objectives of this study were to verify the influence of Viscozyme L pre-treatment of soy slurry on sugars and isoflavones content in treated tofu compared to control and to analyze the microstructure of these different products.

\section{Matherial and Methods}

\subsection{Chemical and Material}

The multi-enzymatic complex Viscozyme L (from Aspergillus aculeatus) was a gift from Novozymes Latin American Inc. (Araucária, PR- Brazil). The activity of Viscozyme L was 100 Fungal Beta-Glucanase Units (FBG) $\mathrm{g}^{-1}$, in which 1 FBG is the amount of enzyme required under the standard conditions $\left(30^{\circ} \mathrm{C}, \mathrm{pH} 5.0\right.$ and $30 \mathrm{~min}$ reaction time) that hydrolyzes barley $\beta$-glucan to reducing carbohydrates, corresponding to $1 \mu$ mol glucose $\mathrm{min}^{-1}$.

The soybean variety BRS 267 (large grains), crop 2007/2008 (EMBRAPA - PR, Brazil), was used to prepare the tofus. The antifoam agent was supplied by Prosabor (São Paulo-Brazil) and GDL (Sigma-Aldrich) was used as coagulant agent. All the other reagents were of analytical grade.

\subsection{Production of Silken Tofu}

The tofus were prepared by a modification of the methods proposed by Min, Yu, and Martin [12] and Shen, De Man, Buzzell, and De Man [13]. Soybeans (approximately $150 \mathrm{~g}$ ) were soaked in $1500 \mathrm{ml}$ distilled water at $25^{\circ} \mathrm{C}$ for $16 \mathrm{~h}$. The soaked soybeans were drained, rinsed and ground with $1000 \mathrm{~mL}$ distilled hot water $\left(98^{\circ} \mathrm{C}\right)$ in a blender for $3 \mathrm{~min}$ at high speed. Antifoam agent (1.0 $\mathrm{mL}$ ) was added to the slurry during grinding.
Viscozyme L (2.5 mL, 30 FBG/10 g solids) was added to $1000 \mathrm{~mL}$ portion of soy slurry. After incubation at $55^{\circ} \mathrm{C}$ for $30 \mathrm{~min}$ [14], the soy suspension was boiled $\left(98^{\circ} \mathrm{C}, 10\right.$ min) and filtered manually with a muslin cloth to obtain soymilk. To a $400 \mathrm{~mL}$ portion of soymilk $\left(45^{\circ} \mathrm{C}\right), 10 \mathrm{~mL}$ of GDL (0.02 M) was added and placed into a plastic container which was transferred to a water bath (Marconi, MA 127) and left at $85^{\circ} \mathrm{C}$ for $60 \mathrm{~min}$. The yield of tofu was calculated as the weight of fresh tofu obtained from a specified amount of the soymilk (400 mL) used for its preparation. Tofus without the enzyme treatment (control) were produced in the same way, excluding only the step of enzyme addition. The tofus were frozen and lyophilized $\left(0.040\right.$ mbar and $\left.-50^{\circ} \mathrm{C}\right)$ in a freeze-dryer (Alpha 2-4 LD Plus, Christ) to determine sugars and isoflavones. The moisture content of lyophilized tofu with enzyme and control was $3.6 \%$ and $2.8 \%$, respectively.

\subsection{Quantification of Soluble Sugars from Tofus}

The extraction of sugars (glucose, fructose and sucrose) and oligosaccharides (raffinose and stachyose) followed the method of Masuda, Kaneko, and Yamashita [15] adapted by Mandarino, Carrão-Panizzi, and Masuda [16] with some modifications. Approximately, $1.0 \mathrm{~g}$ of freeze dried tofu was suspended in $10 \mathrm{~mL}$ of $80 \%$ ethanol, and the dispersion was homogenized for $2 \mathrm{~min}$, with the aid of a Polytron. The samples were centrifuged (Sorvall TC 6, Du Pont) at $2000 \mathrm{x} g$ for $5 \mathrm{~min}$, the supernatant was decanted and to the precipitate another $10 \mathrm{~mL}$ of $80 \%$ ethanol was added for a second extraction. The supernatants were combined in a $50 \mathrm{~mL}$ centrifuge tube and the volume was completed to $25 \mathrm{~mL}$. The content of the tube was homogenised, and $100 \mu \mathrm{L}$ of the clear supernatant was mixed with $1.4 \mathrm{~mL}$ of a $80 \%$ ethanol solution.

Sugars and oligosaccharides were quantified by high performance liquid chromatography (HPLC) in a Dionex Bio LC chromatograph, equipped with automated sampler (TSP, model Spectra System AS 3500) and electrochemical detector with gold electrode (Dionex model ED 50). Sugars were separated on a Dionex CarboPac PA 10 anion-exchange resin column (250 mm x $4 \mathrm{~mm}$ i.d.), preceded by a Dionex CarboPac PA 10 guard column (50 mm x $4 \mathrm{~mm}$ i.d.). The mobile phase consisted of $50 \mathrm{mM} \mathrm{NaOH}$ solution prepared by dilution of carbonate-free $50 \%$ (w/w) $\mathrm{NaOH}$ solution in MilliQ water, with a flow rate of $1.2 \mathrm{~mL} / \mathrm{min}$ at approximately $25^{\circ} \mathrm{C}$.

HPLC identification and quantification of the major sugars present in the samples was achieved by comparing each peak retention time and area with those of external standards. A stock solution composed of glucose, fructose, sucrose, raffinose, and stachyose with concentrations of $40,80,120,160$, and $200 \eta$ moles was prepared for the HPLC system. A standard curve for each sugar was prepared by injecting different concentrations of the stock solution. All sugar analyses were performed in triplicate and results were expressed on a dry-weight basis in g/100 g.

\subsection{Isoflavone Quantification}

The quantitative analysis of isoflavones was conducted according Kudou et al. [17] adapted by Carrão-Panizzi 
and Bordingnon [18]. The tofu samples were freeze-dried and defatted, and these dried samples were used in the isoflavone analyses. Extracting the oil from soybeans or its products does not remove the isoflavones since they are not soluble in hexane. Isoflavones were extracted from $100 \mathrm{mg}$ samples of defatted freeze-dried tofus. Samples were placed in test tubes with $4 \mathrm{ml}$ of $70 \%$ aqueous ethanol containing $0.1 \%$ acetic acid, at $25^{\circ} \mathrm{C}$ and extracted for 1 hour with agitation at 15 min intervals. Then, the tubes were sonicated for 30 minutes and the extract (approximately $1.5 \mathrm{~mL}$ ) were transferred to an Eppendorf tube and centrifuged at $21000 \mathrm{x} \mathrm{g}$ for $10 \mathrm{~min}$ at $5^{\circ} \mathrm{C}$ (Centrifuge Eppendorf, model 5417R). After centrifugation, the supernatants were filtered into vial through Millex $0.45 \mu \mathrm{m}$ using a syringe filter (Arti Glass SRL, Italy) and transferred to the auto sampler ( $20 \mu \mathrm{l}$ was the volume injected). Analysis of isoflavones was performed with a reverse-phase column (CLC-ODS (M) C18, $4.6 \mathrm{~mm}$ internal diameter x $250 \mathrm{~mm}, 5 \mathrm{~mm}$ particles). The mobile phase (solvent A) was a solution of acetonitrile and $0.1 \%$ acetic acid, while solvent B was a solution of water and $0.1 \%$ acetic acid. Initial gradient was $20 \%$ for the solvent $\mathrm{A}$ in the first 20 minutes, passing to $100 \%$ for 5 minutes and $20 \%$ for the last 15 minutes. The isoflavonas were detected at $260 \mathrm{~nm}$. The complete elution of each sample was performed in 40 minutes. Standard solutions of daidzin, daidzein, genistin and genistein (Sigma-Aldrich) were $0.0125 \mathrm{mg} / \mathrm{ml}$. The isoflavone contents were expressed in $\mathrm{mg} / 100 \mathrm{~g}$ of tofu on a dry weight basis.

\subsection{Scanning Electron Microscopic Observation}

The procedure used for sample preparation was that of Kao, Su, and Lee [19] with some modifications. A small piece of each tofu sample was pre-fixed at $25^{\circ} \mathrm{C}$ with $2.5 \%$ glutaraldehyde in $0.1 \mathrm{M}$ phosphate buffer ( $\mathrm{pH} 7.0$ ) for $4 \mathrm{~h}$. The samples were freeze-fractured in liquid nitrogen and washed (three times) with $0.1 \mathrm{M}$ phosphate buffer ( $\mathrm{pH} \mathrm{7.0)}$ at 15 min intervals, and were then postfixed with $1 \%$ osmium tetroxide in the same buffer for 60 min at room temperature. The fixed samples were again rinsed three times with phosphate buffer at $15 \mathrm{~min}$ intervals. Then the samples were dehydrated in a graded series of ethanol solutions (70\%, 80\%, 90\% and 100\%). The samples in alcohol were placed into a vacuum evaporator to sublimate the ethanol (Critical Point Dryer CPD 010, Bal-Tec). After sublimation, the dried samples were fixed in the microscope stub by using double-sided adhesive carbon-tapes. The broken side of each cubic sample faced the top of the aluminium stub and was sputter-coated with gold (Sputter Coater model SCD 050, Bal-Tec). The observations were carried out at $20 \mathrm{kV}$ by a scanning electron microscope (model Quanta 200, FEI).

\subsection{Statistical Analyses}

All extractions and determinations were performed in triplicate. Results are expressed on a dry matter basis as mean values \pm standard deviation. Analysis of variance (ANOVA) was conducted for the data collected, using Statistica 7.0 for Windows [20]. Differences among the mean values were determined using Student t-test. A significant level was defined as a probability of 0.05 .

\section{Results and Discussion}

\subsection{Sugars and Oligosaccharides}

A HPLC chromatogram of the sugars from control tofu and treated tofu is show in Figure 1 (A and B, respectively). Total sugars were 11.69 in treated tofu and $8.93 \mathrm{~g} / 100 \mathrm{~g}$ in control sample, a 30.9\% increase (Table 1). Control tofu had as major sugar sucrose $3.77 \mathrm{~g} / 100 \mathrm{~g}$, followed by stachyose $3.30 \mathrm{~g} / 100 \mathrm{~g}$, with fructose being the minor component, $0.36 \mathrm{~g} / 100 \mathrm{~g}$. The treated sample had $4.58 \mathrm{~g} / 100 \mathrm{~g}$ of stachyose, the predominant oligosaccharide, followed by $3.08 \mathrm{~g} / 100 \mathrm{~g}$ of sucrose, but with a higher concentration of fructose and glucose compared to the control sample. Glucose had twice the concentration, $1.66 \mathrm{~g} / 100 \mathrm{~g}$ and fructose three times more than control with $1.09 \mathrm{~g} / 100 \mathrm{~g}$. During silken tofu manufacturing, there is no removal of whey like in soft tofu, so soluble sugars present in the soymilk will remain in the tofu. Treated tofu could have a sweeter taste (more glucose and fructose) and had more oligosaccharides (raffinose and stachyose) than control tofu.
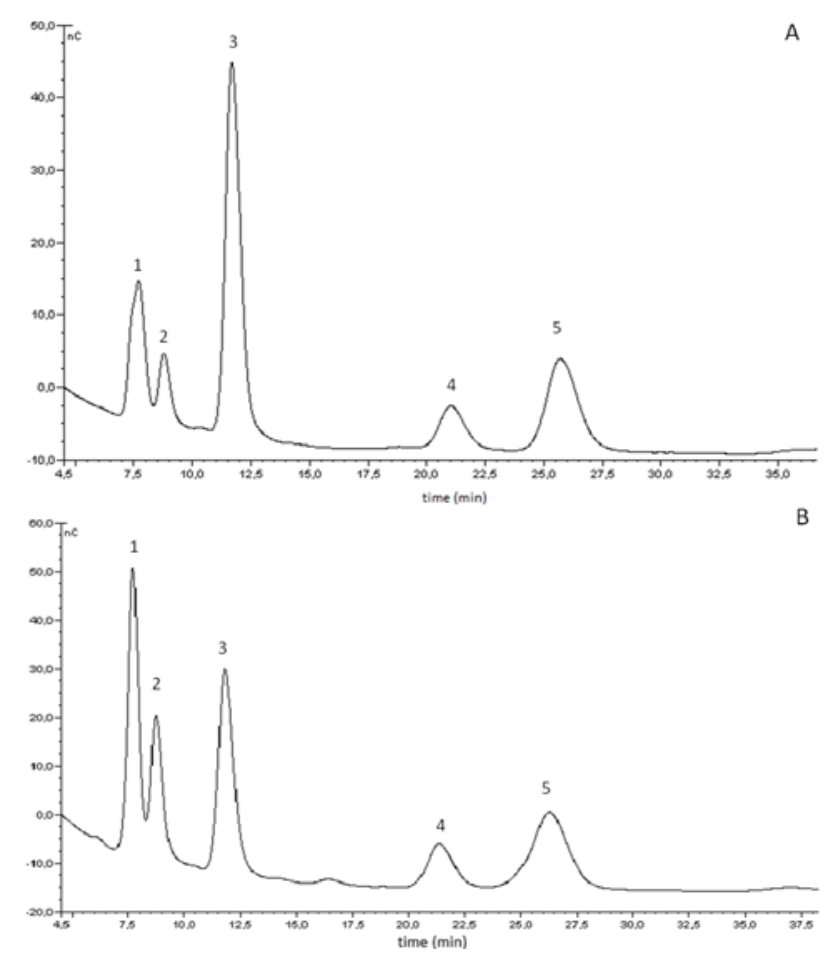

Figure 1. Separation of sugars in control (A) and treated tofu (B). Glucose (1), fructose (2), sucrose (3), rafinose (4) and stachyose (5)

Soybean oligosaccharides, raffinose and stachyose, which resist digestion due to the $\alpha$-galactoside linkages in their structure have prebiotic effects, and studies have shown that their consumption is related to several health benefits, such as lowering blood cholesterol, reducing blood pressure and preventing some types of cancer [4]. The treated tofu had a total of 5.79 and control had 4.05 $\mathrm{g} / 100 \mathrm{~g}$ of oligosaccharides, an increase of $43 \%$.

Considering the sugars determined in the Brazilian cultivar BRS 297 in 2010, 150 g of soy used for tofu production had a calculated amount of $8.92 \mathrm{~g}$ of sucrose and $3.34 \mathrm{~g}$ of stachyose, of which 3.56 and 1.33 would be in the $400 \mathrm{~mL}$ of soy milk used in the tofu, but these values were present in defatted soy flour and would be less in the soybean grain. The amounts found in the tofus 
were higher for stachyose and sucrose as calculated, but the amount really present in the grain was not determined.

Table 1. Sugar Composition (g/100 g, db) of Tofus

\begin{tabular}{ccc}
\hline Sugar & Control tofu & Treated tofu \\
\hline Glucose & $0.74 \pm 0.02^{\mathrm{b}}$ & $1.66 \pm 0.08^{\mathrm{a}}$ \\
Fructose & $0.36 \pm 0.02^{\mathrm{b}}$ & $1.09 \pm 0.03^{\mathrm{a}}$ \\
Sucrose & $3.77 \pm 0.26^{\mathrm{a}}$ & $3.08 \pm 0.03^{\mathrm{a}}$ \\
Raffinose & $0.75 \pm 0.01^{\mathrm{b}}$ & $1.21 \pm 0.04^{\mathrm{a}}$ \\
Stachyose & $3.30 \pm 0.19^{\mathrm{b}}$ & $4.58 \pm 0.16^{\mathrm{a}}$ \\
Total sugars & $8.93 \pm 0.50^{\mathrm{b}}$ & $11.69 \pm 0.34^{\mathrm{a}}$ \\
\hline
\end{tabular}

Means values in the same row followed by different letters are different

(Student t-test, $\mathrm{p} \leq 0.05$ )

\subsection{Isoflavones}

A HPLC chromatogram of the isoflavones extracted from control tofu and treated tofu is show in Figure 2 (A and $\mathrm{B}$, respectively). Aglycons with the exception of genistein, which was lower in treated tofu, had equal concentrations. $\beta$-glucosides were lower in treated tofus than in control, since the carbohydrases could have deesterified the glucose molecule. The levels of malonyl conjugates were approximately double compared to control (Table 2). Apparently the amount of malonyl forms initially present in the soybean grain were less altered in the treated tofu while the $\beta$-glucosides had a higher level of hydrolysis. The concentrations found of the various forms of isoflavones in the control tofu were very similar to the values reported by Wang and Murphy [21].

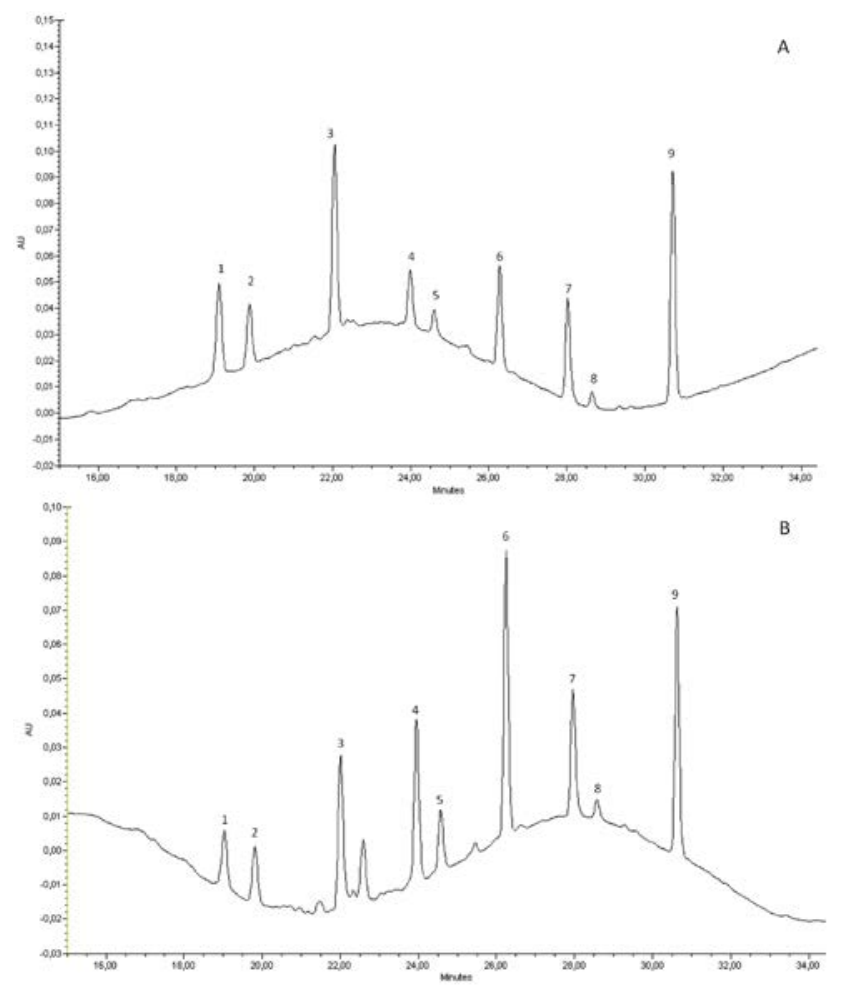

Figure 2. A HPLC profile of isoflavones extracted from control tofu (A) and treated tofu (B). The peaks are identified as 1. Daidzin, 2. Glycitin, 3. Genistin, 4. Malonyldaidzin, 5. Malonylglycitin, 6. Malonylgenistin, 7. Daidzein, 8. Glycitein, 9. Genistein.

Soybean grains had the majority of the compounds in the malonyl and $\beta$ - glucosides forms with very low amounts of aglycon forms and in the produced tofu there was an increased amount of aglycons [21] who found 7.2, 13.2 and $5.5 \mathrm{mg} / 100 \mathrm{~g}$ while we found 9.85, 16.14 and
$2.89 \mathrm{mg} / 100 \mathrm{~g}$ for daidzein, genistein an glycitein and no difference with the concentration in control tofu.

Table 2. Isoflavones Composition (mg/100 g, db) of Tofus

\begin{tabular}{ccc}
\hline Isoflavone & Control tofu & Treated tofu \\
\hline Daidzein & $10.44 \pm 0.77^{\mathrm{a}}$ & $9.85 \pm 0.93^{\mathrm{a}}$ \\
Glycitein & $2.93 \pm 0.16^{\mathrm{a}}$ & $2.89 \pm 0.09^{\mathrm{a}}$ \\
Genistein & $19.94 \pm 0.03^{\mathrm{a}}$ & $16.14 \pm 0.11^{\mathrm{b}}$ \\
Daidzin & $22.20 \pm 0.63^{\mathrm{a}}$ & $10.92 \pm 0.46^{\mathrm{b}}$ \\
Glycitin & $14.24 \pm 0.27^{\mathrm{a}}$ & $10.14 \pm 0.57^{\mathrm{b}}$ \\
Genistin & $28.90 \pm 1.75^{\mathrm{a}}$ & $18.15 \pm 1.39^{\mathrm{b}}$ \\
Malonyldaidzin & $11.65 \pm 0.12^{\mathrm{b}}$ & $26.58 \pm 0.59^{\mathrm{a}}$ \\
Malonylglycitin & $7.91 \pm 1.01^{\mathrm{b}}$ & $15.65 \pm 1.61^{\mathrm{a}}$ \\
Malonylgenistin & $15.32 \pm 0.45^{\mathrm{b}}$ & $32.77 \pm 0.19^{\mathrm{a}}$ \\
\hline
\end{tabular}

Means values in the same row followed by different letters are different (Student t-test, $\mathrm{p} \leq 0.05$ ).

Hui, Henning, Park, Heber, \& Go [22] determined the variation of the isoflavone content of 23 commercially available packaged tofus by brands and batches. Among different tofu brands the genistein and daidzein/glycitein content varied from 0.38 to $1.47 \mathrm{mg} / 100 \mathrm{~g}$ and 0.39 to $1.14 \mathrm{mg} / 100 \mathrm{~g}$ dry basis, respectively. The isoflavone content from batch to batch of the same brand varied between 7 and 28\% based on dry weight. According Hui et al. [22], assuming a daily consumption of $30 \mathrm{~g}$ commercial tofus products, the isoflavone intake could vary between 2.1 to $13.2 \mathrm{mg}$ /day, with higher levels in pressed tofus. Considering our tofus, with approximately $91 \%$ of water, the intake could vary between 3.6 and 3.9 $\mathrm{mg} /$ day for control and enzyme treated tofu, respectively.

Fukutake et al. [23] reported lower amounts of genistein e genistin in tofu (94.8 to $137.7 \mu \mathrm{g} / \mathrm{g}$ ), probably tofus produced by pressing the curd when the isoflavones were probably liberated with the whey, since they are water soluble. So there is an advantage in producing silken tofu to obtain more isoflavones compared to other types of tofus. In non-fermented soy products, isoflavones are present mainly as $\beta$-glucoside conjugates like we found in the control tofu (Table 2).

From the grain to the tofu losses of isoflavones occur in okara separation, about $12 \%$, and during pressing about $44 \%$ while the remaining $33 \%$ was associated with the soluble proteins in the tofu [21], but these results are determined by the amount initially present in the soy grain.

Total amounts of the three forms of isoflavones normalized for their molecular weights resulted in the same amounts in treated and control tofus (Table 3). Total daidzein was $29.93 \mathrm{mMol} / 100 \mathrm{~g}$; total genistein 45.28 $\mathrm{mMol} / 100 \mathrm{~g}$ and total glycitein $16.96 \mathrm{mMol} / 100 \mathrm{~g}$ of tofu. The total amount of isoflavones was then $92.16 \mathrm{mMol} / 100$ g of tofu.

Table 3. Isoflavones Composition (mMol/100 g, db) of Tofus

\begin{tabular}{ccc}
\hline Isoflavone & Control tofu & Treated tofu \\
\hline Total Daidzein & $29.89 \pm 0.43^{\mathrm{a}}$ & $29.97 \pm 1.12^{\mathrm{a}}$ \\
Total Glycitein & $16.22 \pm 0.48^{\mathrm{a}}$ & $17.70 \pm 0.81^{\mathrm{a}}$ \\
Total Genistein & $45.99 \pm 0.96^{\mathrm{a}}$ & $44.56 \pm 1.06^{\mathrm{a}}$ \\
Total Isoflavones & $92.09 \pm 0.93^{\mathrm{a}}$ & $92.23 \pm 1.95^{\mathrm{a}}$ \\
\hline
\end{tabular}

Means values in the same row followed by different letters are different (Student t-test, $\mathrm{p} \leq 0.05$ ). Total daidzein, total genistein, total glycitein, and total isoflavones were calculated by adjusting for the molecular weights of the different isoflavones using the following formulas: total daidzein= 254.23 (daizin/416.36 + 6”-O-malonyldaidzin/ 502.411 +6”O-acetyldaidzin/458.41 + daidzein/254.23), total genistein $=270.23$ (genistin/ $432.37+6$ "'-Omalonylgenistin/ $518.411+6$ "'-Oacetylgenistin/474.41 + genistein/270.23), total glycitein $=284$ (glycitin/ 446 + 6"-O-malonylglycitin/532 + 6"-O-acetylglycitin/ $488+$ glycitein/ 284), and total isoflavones $=$ total daidzein + total genistein + total glycitein. 


\subsection{Scanning Electron Microscopic Structure}

Under high magnification (10.000 and $12.000 \mathrm{X}$ ) both tofu samples had a globular microstructure of protein aggregates and showed a fibrous three-dimensional network structure (Figure 3). Fine structures of tofu could be classified by the network density, protein aggregation and size of coagulants. It has been reported that the denser the network and the larger the protein aggregates in the structure the harder is the tofu [13,24].

There were differences in size and density of the particles between the tofu samples. The treated tofu was organized with a well-defined three-dimensional honeycomb-like network with empty spaces or pores
(Figure 3, A and C). The predominant forces in protein aggregation in tofu are hydrophobic interactions and the open spaces are due to the liquid phase present before dehydration during sample preparation for SEM observation. The control tofu had larger protein aggregates and was more tightly connected with filaments than the treated tofu (Figure 3, B and D). This was in agreement with the report of Han and Kim [24], where the chitooligosaccharide tofu was organized with some vacant spaces in its network and the control tofu had larger protein aggregates and was more tightly connected between protein aggregates than the chitooligosaccharide tofu.
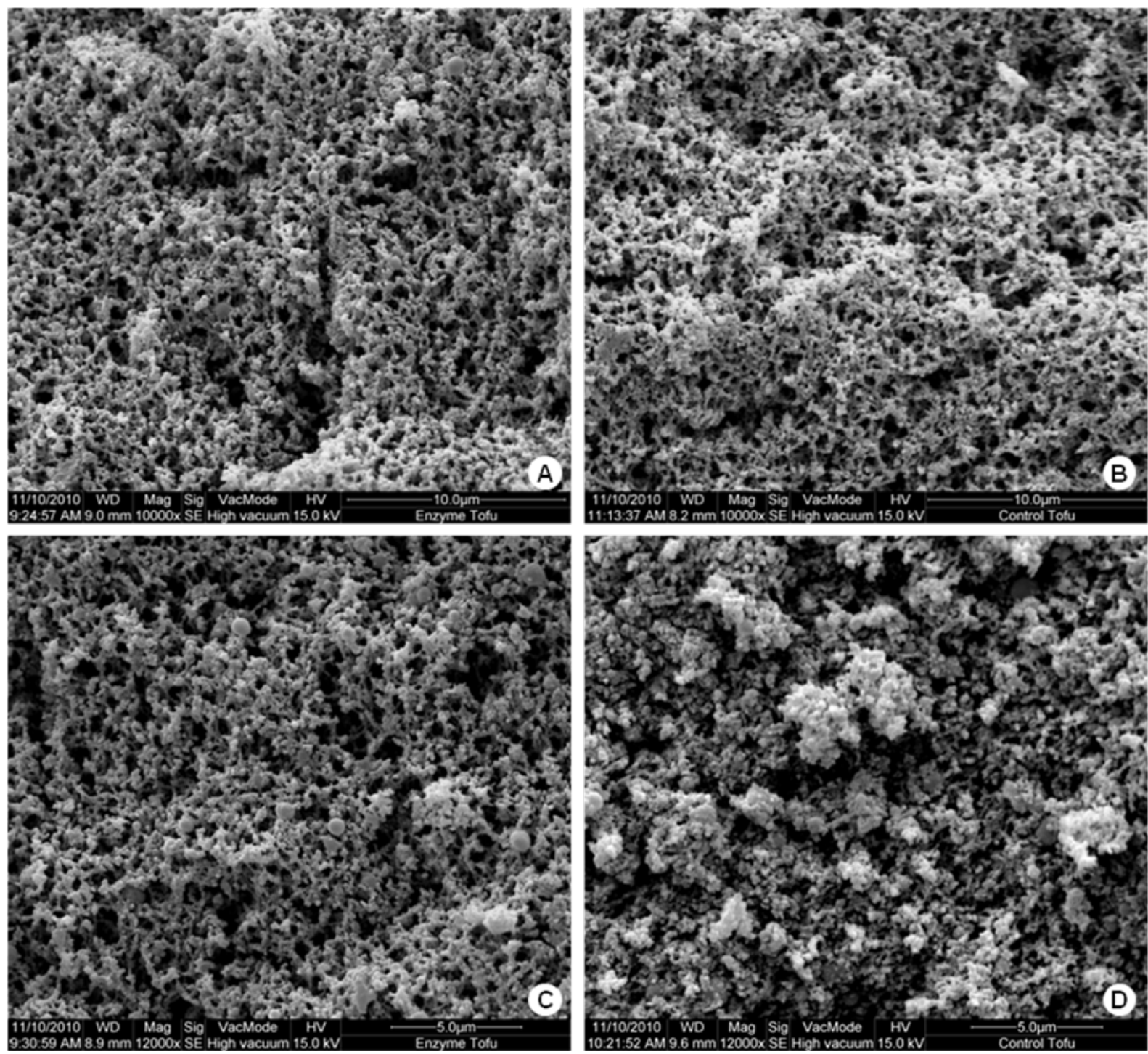

Figure 3. Scanning electron microscopic image of tofu treated with Viscozyme L (A, C) and control tofu (B, D)

The water holding capacity (WHC) increases significantly due to decreased protein-protein interaction resulting in formation of large pores. The presence of sugars may interfere in these interactions. According to Boye, Alli, Ramaswamy, \& Raghavan [25], the WHC of gelled whey protein concentrate heated at neutral $\mathrm{pH}$ increased with increased sucrose concentrations. Their explanation was that sucrose decreased aggregate formation thus increased the WHC, which could be attributed to increased solvation of sucrose trapped within interstitial spaces of the whey protein gel. Gu et al. [11] reported that the gels containing sugars were able to retain more water than the control gel; and the WHC of reducing sugar samples was higher than the sample containing nonreducing sugar. A HPLC chromatogram of the isoflavones extracted from control tofu and treated tofu is show in Figure 2 (A and B, respectively). Aglycons with the exception of genistein, which was lower in treated tofu, had equal concentrations. $\beta$ - glucosides were lower in treated tofus than in control, since the carbohydrases could have de-esterified the glucose molecule. The levels of malonyl conjugates were approximately double compared 
to control (Table 2). Apparently the amount of malonyl forms initially present in the soybean grain were less altered in the treated tofu while the $\beta$-glucosides had a higher level of hydrolysis. The concentrations found of the various forms of isoflavones in the control tofu were very similar to the values reported by Wang and Murphy [21].

\section{Conclusion}

The level of glucose, fructose and raffinose were approximately duplicated in treated tofu compared to control. The isoflavones content did not vary with enzymatic treatment and total amount of the compounds was the same for both samples. Malonyl had a higher concentration in the treated tofu while the control had more $\beta$-glucosides. Both tofu samples had a globular microstructure of protein that was integrated into clumps and showed a fibrous three-dimensional network structure.

\section{Acknowledgement}

The authors thank CAPES for the financial support.

\section{References}

[1] Hymowitz, T., Collins, F. I., Panczner, J., \& Walker, W. M., "Relationship between the content of oil, protein and sugars in soybeans seed,” Agronomy Journal, 64 (2), 613-616, 1972.

[2] Oliveira, M. A., Carrão-Panizzi, M. C., Mandarino, J. M. G., Leite, R. S., Campos Filho, P. J., \& Vicentini, M. B., "Quantification of the sugars, oligosaccharides and starch in special soybean genotypes/cultivars (Glycine Max (L) Merril) for human consumption,” Brazilian Journal of Food Technology, 13 (1), 2329, 2010.

[3] Taira, H., "Quality of soybean for processed foods in Japan,” Japanese Agricultural Research Quarterly, 24 (3), 224-230, 1990.

[4] Mussatto, S. I., \& Mancilha, I. M., "Non-digestible oligosaccharides: A review,” Carbohydrate Polymers, 68 (3), 587597, 2007.

[5] Coward, L., Barnes, N. C., Setchell, K. D. R., \& Barnes, S., "Genistein, daidzein, and their $\beta$-glycoside conjugates: antitumor isoflavones in soybean foods from American and Asian diets,” Journal of Agricultural and Food Chemistry, 41 (11), 1961-1967, 1993.

[6] Bedani, R., \& Rossi, E. A., “Isoflavonas: bioquímica, fisiologia e implicações para a saúde,” Boletim CEPPA, 23 (2), 231-264, 2005.

[7] Martínez, J. M. G., "Isoflavonas en mujeres menopáusicas”, Medicina Clínica, 127 (9), 352-356, 2006.

[8] Liu, K., "Soybeans: Chemistry, Technology and Utilization," Chapman \& Hall, New York, 1997, 165-198.
[9] Coward, L., Smith, M., Kirk, M., \& Barnes, S., "Chemical modification of isoflavones in soyfoods during cooking and processing," The American Journal of Clinical Nutrition, 68 (6), 1486 S-1491 S, 1998.

[10] Anon, Product sheet of Viscozyme L. Novo Nordisk A/S, Enzymes process division, Bagsvaerd, Denmark, 2008.

[11] Gu, X., Campbell, L. J., \& Euston, S. R., "Influence of sugars on the characteristics of glucono- $\delta$-lactone-induced soy protein isolate gels,” Food Hydrocolloids, 23 (2), 314-326, 2009.

[12] Min, S., Yu, Y., \& Martin, S. ST., "Effect of soybean varieties and growing locations on the physical and chemical properties of soymilk and tofu,” Journal of Food Science, 70 (1), C 8-C 12, 2005.

[13] Shen, C. F., De Man, L., Buzzell, R. I., \& De Man, J. M., "Yield and quality of tofu as affected by soybean and soymilk characteristics: Glucono-delta-lactone coagulant,” Journal of Food Science, 56 (1), 109-112, 1991.

[14] Rosset, M., Prudencio, S. H., \& Beléia, A. D. P., "Viscozyme L action on soy slurry affects carbohydrates and antioxidant properties of silken tofu," Food Science and Technology International, 18 (6), 531-538, 2012.

[15] Masuda, R., Kaneko, K., \& Yamashita, I., "Sugar and cyclitol determination in vegetables by HPLC using postcolumn fluorescent derivatization,” Journal of Food Science, 61 (6), 11861190, 1996.

[16] Mandarino, J. M. G., Carrão-Panizzi, M. C., \& Masuda, R., "Composition content of sugars in soybean seeds of Brazilian cultivars and genotypes of Embrapa Germoplasm collection,” in International Soybean Processing and Utilization Conference, Tsukuba: Korin Publishing, 77-78, 2000.

[17] Kudou, S., Fleury, Y., Welti, D., Magnolato, D., Uchida, T., Kitamura, K., \& Okubo, K., "Malonil isoflavone in soybeans seeds (Gyicine max [Merrill])," Agriculture and Biological Chemistry, 55 (9), 2227- 2233, 1991.

[18] Carrão-Panizzi, M. C., \& Bordingnon, J. R., “Activity of betaglucosidase and levels of isoflavone in soybeans cultivars affected by the environment," Pesquisa Agropecuária Brasileira, 35 (5), 873-878, 2000.

[19] Kao, F. J., Su, N. W., \& Lee, M. H., "Effect of calcium sulfate concentration in soymilk on the microstructure of firm tofu and the protein constitutions in tofu whey," Journal of Agricultural and Food Chemistry, 51 (21), 6211-6216, 2003.

[20] STATSOFT, Statistica for Windows, Tulsa: Stasoft, 2007.

[21] Wang, H. J, \& Murphy, P. A., "Mass balance study of isoflavones during soybean processing," Journal of Agriculture and Food Chemistry, 44 (8), 2377-2383, 1996.

[22] Hui, E., Henning, S. M., Park, N., Heber, D., \& Go V. L. W., "Genistein and daidzein/glycitein content in tofu," Journal of Food Composition and Analysis, 14 (2), 199-206, 2001.

[23] Fukutake, M., Takahashi, M., Ishida, K., Kawamurai, H., Sugimura, T., \& Wakabayashi, K., "Quantification of genistein and genistin in soybeans and soybean products," Food and Chemical Toxicology, 34 (5), 457-461, 1996.

[24] Han, J. S., \& Kim, M., "Effects of chitooligosaccharide on the physicochemical, textural and sensory properties of tofu," Journal of Texture Studies, 33 (1), 1-14, 2002.

[25] Boye, J. I., Alli, I., Ramaswamy, H., \& Raghavan, V. G. S., "Interactive effects of factors affecting gelation of whey protein," Journal of Food Science, 62 (1), 57-65, 1997. 